\title{
Glaciotectonically deformed glaciofluvial sediments with ruptured pebbles (the Koczery study site, E Poland)
}

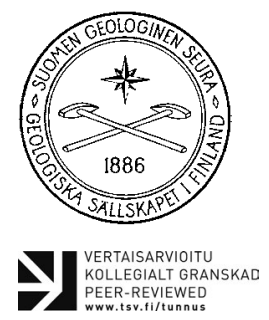

Barbara Woronko ${ }^{1}$, Szymon Belzyt² ${ }^{2}$ Łukasz BujaK ${ }^{3}$ and Maegorzata Pisarska-Jamroż ${ }^{2}{ }^{*}$

${ }^{1}$ Faculty of Geology, Warsaw University, Żwirki $i$ Wigury 93, 02-089 Warsaw, Poland ${ }^{2}$ Institute of Geology, Adam Mickiewicz University, B. Krygowskiego 12, 61-680 Poznań, Poland

${ }^{3}$ Faculty of Geodesy and Cartography, Warsaw University of Technology, Plac Politechniki 1, 00-661, Warsaw, Poland

\begin{abstract}
Significant quantities of ruptured pebbles are found in glaciotectonically deformed glaciofluvial sediments of the Saalian glaciation (MIS 6) at the Koczery site (E Poland). To identify the responsible mechanisms for the pebble-rupture activity, structural, petrographic, roundness and shape analyses were done. Additionally, till fabric of overlying glacial diamicton was analysed and compared to the other outcomes. The origin of fractures in ruptured pebbles of glaciofluvial sediments is directly linked to compressive stress caused by glaciotectonic processes because of 1) ruptured pebbles occur mainly in glaciotectonically deformed sediments (a quarter of all pebbles is fractured); 2) ruptured pebbles almost always occur one-by-one primarily in gravelly lithofacies; 3) fractures occur in pebbles derived from all petrographic groups; 4) fracture occurrence is independent of pebbles size, shape and roundness; 5) fractures mostly occur parallel to each other (along long 'a' or short 'c' axis of pebbles) and parallel to the bedding of lithofacies; and 6) in most cases broken fragments of ruptured pebbles survived in the host sediment indicating that the observed damage occurred in situ. This novel study of ruptured pebbles found in glacigenic environments sheds new light on the dynamics of glaciotectonic processes, and may be useful in the characterization of palaeostresses that occur during glaciotectonic deformations.
\end{abstract}

Keywords: ruptured pebbles, glaciofluvial sediments, glaciotectonic deformations, palaeostress, end moraine

*Corresponding author (e-mail: pisanka@amu.edu.pl)

Editorial handling: Pertti Sarala (pertti.sarala@gtk.fi) 


\section{Introduction}

Ruptured clasts (fractured clasts, ruptured pebbles) have been described from tectonic zones that are active or have been active in geological past (Ramsay, 1962, 1964; Tapponnier et al., 1986; Eidelman \& Reches, 1992; Decker \& Peresson, 1996; Tokarski \& Świerczewska, 2005; Badura et al., 2007; Grützner et al., 2012; Tokarski et al., 2016; Kübler et al., 2017), and are reported from fluvial terraces of Pleistocene and Holocene age (Tanner, 1976; Eildeman \& Reches, 1992; Tokarski et al., 2007). One potential causal agent has been attributed to the intra-pebble stress increase associated with the intensification of tectonic forces (Eidelman \& Reches, 1992). A common feature of layers that accommodate ruptured pebbles is their close proximity to map-scale faults (Ramsay, 1962, 1964; Tanner, 1963, 1976; Tyler, 1975; Bradley \& Bradley, 1986; Tapponnier et al., 1986; Lamb \& Bibby, 1989; Owen, 1989; Eidelman \& Reches, 1992; Little, 1995; Decker \& Peresson, 1996; Cuong et al., 2001; Badura et al., 2007; Tokarski et al., 2007, 2016). Most researchers argue that the quantity of ruptured clasts increases towards fault sites (Ramsay, 1964; Tanner, 1976; Bradley \& Bradley, 1986; Little, 1995; Grützner et al., 2012; Tokarski et al., 2016). All previous research of ruptured pebbles has focused on several issues: 1) fracture architecture (e.g., Kupsch, 1955; Eidelman \& Reches, 1992; Tokarski et al., 2007; Grützner et al., 2012; Kübler et al., 2017); 2) orientation of fractures in relation to compressive stress (Ramsay, 1964; Eildelman \& Reches, 1992), 3) petrography of fractured clasts (Kupsch, 1955) and 4) using fractured clasts as an indicator of fault timing and fault kinematic analysis (Tanner, 1976; McCaffrey \& McCann, 1992; Little, 1995; cf. Hippolyte, 2001; Badura et al., 2007; Grützner et al., 2012; Kübler et al., 2017).

It is noted here that ruptured pebbles are rarely categorized apart from tectonic factors. As first described by Kupsch (1955), ruptured boulders found in drumlins in the vicinity of Dollard, Saskatchewan, were interpreted to be the manifestation of a simple compressive force in reaction to the movement of glacial ice against the frontal part of the drumlin. Given that ice-marginal Quaternary sediments are commonly found almost all over the world, one would expect the phenomenon of pebble fracturing in corresponding glacial environments be common too. Furthermore, ruptured pebbles are common in glaciotectonically deformed sediments (e.g., Broster \& Clague, 1987; Zelčs \& Dreimanis, 1997; Kinnunen, 2007; Nývlt \& Hoare, 2011) but the relationship between the clasts roundness, petrographic group and occurrence of fractures in clasts have not been described. Additionally, a relationship between the plane direction of clast fractures and the sediment bedding planes, in which the clasts occur, was noticed.

Extraordinary sediments enriched in significant quantities of ruptured pebbles is observed in the glaciotectonically deformed glaciofluvial sediments at the Koczery site in E Poland (Fig. 1a). The main goal of the present study was to unravel the origin of pebble fractures as observed in the study site and establish possible petrographical or geometrical (size, shape) preferences that might influence pebbles' vulnerability to fracturing. Given all the previous research assumptions on this topic, we hoped to determine if the standard invocation of a tectonic factor towards ruptured pebble formation in Pleistocene sediments had been overestimated. Furthermore, the possibility that glaciotectonic dynamics are involved in the development of ruptured pebbles would shed new light on deformation conditions in front of a transgressive ice sheet.

\section{Geological setting}

The Koczery site is located in eastern Poland on the southern part of the Drohiczyn Plateau, close to the maximum extent of the Saalian ice sheet (Marks et al., 2018; Fig. 1a). The study site is an exposure at an end moraine (glaciomarginal fan) deposited during Saalian glaciation (MIS 6; Górska, 2006; Nitychoruk et al., 2009). End moraines here are small hummocks, rising up to $5 \mathrm{~m}$ above the 
surrounding flat till plain, which in elevation reach $160-170 \mathrm{~m}$ a.s.l. (Fig. 1b, c). The glacial diamicton (till) thickness in till plain reaches up to $26 \mathrm{~m}$ (Nitychruk et al., 2009). The till plain lies northward and north-westward of the end moraines, and is inclined $2-5^{\circ}$ eastward and southward according to the relatively steep slope of till plain.

The studied end moraine at the Koczery site incorporates 25-m-thick glaciofluvial sediments covering an area of $-0.5 \mathrm{~km}^{2}$. All glacigenic sediments in the study area were glaciotectonically deformed during the re-advance of the Saalian ice sheet (Warta Stadial during Odranian Glaciation), causing the development of folds, faults (Fig. 2) and vertical dykes. The northern, eastern and western part of the end moraine is covered on average by a 2-3 m thick glacial diamicton. The till thickness decreases towards the southwest, whereas no till cover occurs in the extreme southwestward portion of the end moraine. The glacial diamicton thickness significantly increases up to $5-7 \mathrm{~m}$ close to the glaciotectonically deformed glaciofluvial sediments. The lower boundary of glacial diamicton is distinct and inclined $18-20^{\circ}$ northwards. The contact between glaciofluvial sediments and overlying glacial diamicton is sharp. Furthermore, in glacial diamicton occur oversized, angular soft sediment rafts (1-1.5 m wide and 5-10 m long) with well-preserved original structures, eroded from underlying glaciofluvial sediments.

\section{Methods}

At the Koczery site, glaciofluvial sediments were investigated and recorded as a part of outcrop (Fig. 1d) with four test areas of $2 \mathrm{~m}^{2}$ (walls I-IV; Fig. 3a), supplemented with two parts of outcrop taken from glacial sediments and recorded as $\mathrm{B}$ and $\mathrm{C}$ (Fig. 1d). Textural and structural features of glaciofluvial sediments were described along with glacial sediments using a lithofacies code following Zieliński \& Pisarska-Jamroży (2012). The orientation of bedding within glaciofluvial sediments and fracture planes of ruptured clasts
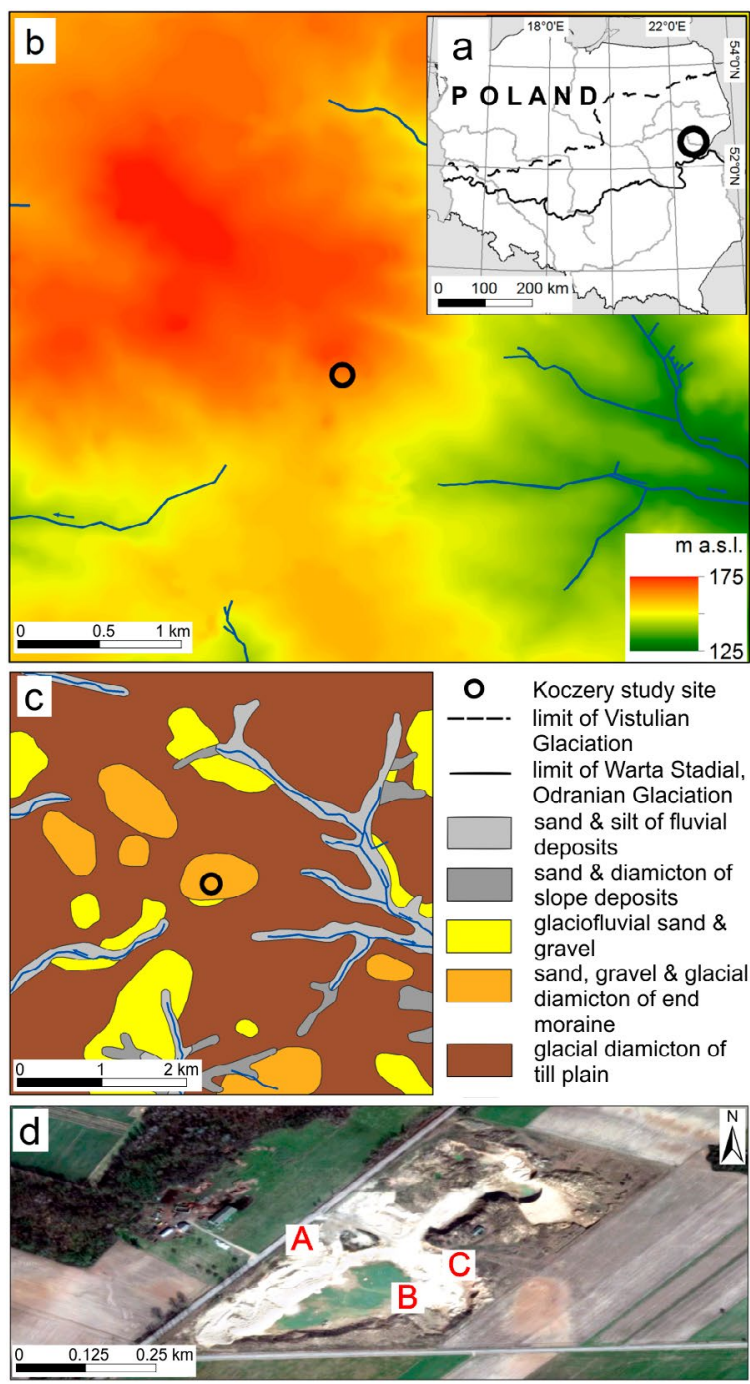

Figure 1. Location of the study site. (a) Extent of the Warta Stadial during Odranian Glaciation (Saale glaciation) in Poland (Marks et al., 2017). (b) Simplified topographic elevation model with location of the study site. (c) Geological map of study area. (d) Location of study outcrop based on Google Earth view (A-C: parts of outcrops described in the text).

and azimuth of clast a-axes within glaciofluvial as well as in glacial diamictons was measured in the field. All measurement results were projected and the fold limbs orientation as well as fold-axis plunge was calculated (walls I-IV) using Stereonet software. Then orientation of 110 pebbles from glacial diamicton in B (50 clasts) and C (60 clasts) parts of outcrop were measured and till fabric was analysed. 

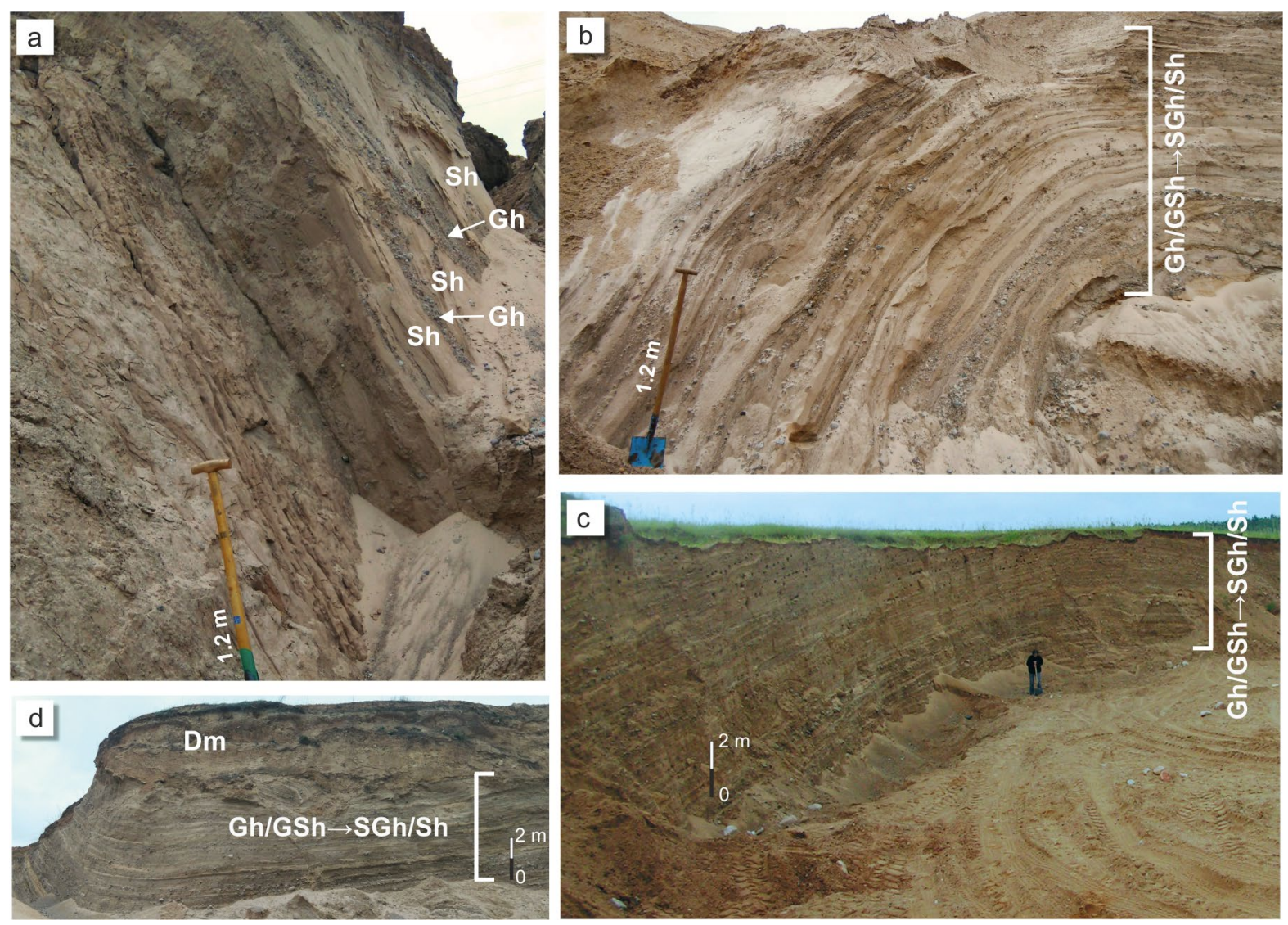

Figure 2. Glaciotectonic deformed sediments in the Koczery outcrop (Photos a-d derived from part A of outcrop; Sh-horizontally bedded sand, SGh-horizontally bedded gravelly sand, GSh-horizontally bedded sandy gravel, Gh-horizontally bedded gravel, Dm-massive diamicton). Lithofacies code after Zieliński \& Pisarska-Jamroży (2012).

The till fabric orientation as identified from the basal glacial diamicton covering glaciofluvial sediments can help in the reconstruction of palaeodirections of ice sheet advance (cf. Benn, 2004).

To determine the vulnerability of the clasts to fracturing under stress, $0.5-10 \mathrm{~cm}$ pebbles present in glaciofluvial sediments were analysed for: 1) petrographic qualities; 2) roundness; and 3) shape analysis (walls I and II; Fig. 1d). According to the petrographic analysis, these pebbles were then divided into four main groups: crystalline rocks, Palaeozoic limestones, sandstones/mudstones and dolomites. Clast roundness of the ruptured and intact (unruptured) pebbles was described using the scale of Reichelt (1961): angular, subangular, subrounded and rounded. Additionally, these fractured pebbles were further distinguished following Olsen (1983), and a 5th grade of fractured pebbles was appended to reflect the percentage of the subangular, subrounded and rounded clasts that were so fractured. Finally, according to the classification of Zingg (1935), the shape of clasts was measured based on ratios of (a) maximum, (b) intermediate and (c) minimum clast axis. Depending on the length of the axes, the ruptured pebbles were then divided into four different categories: oblate (disk), equiaxial (sphere), triaxial (bladed) and prolate (roller). 


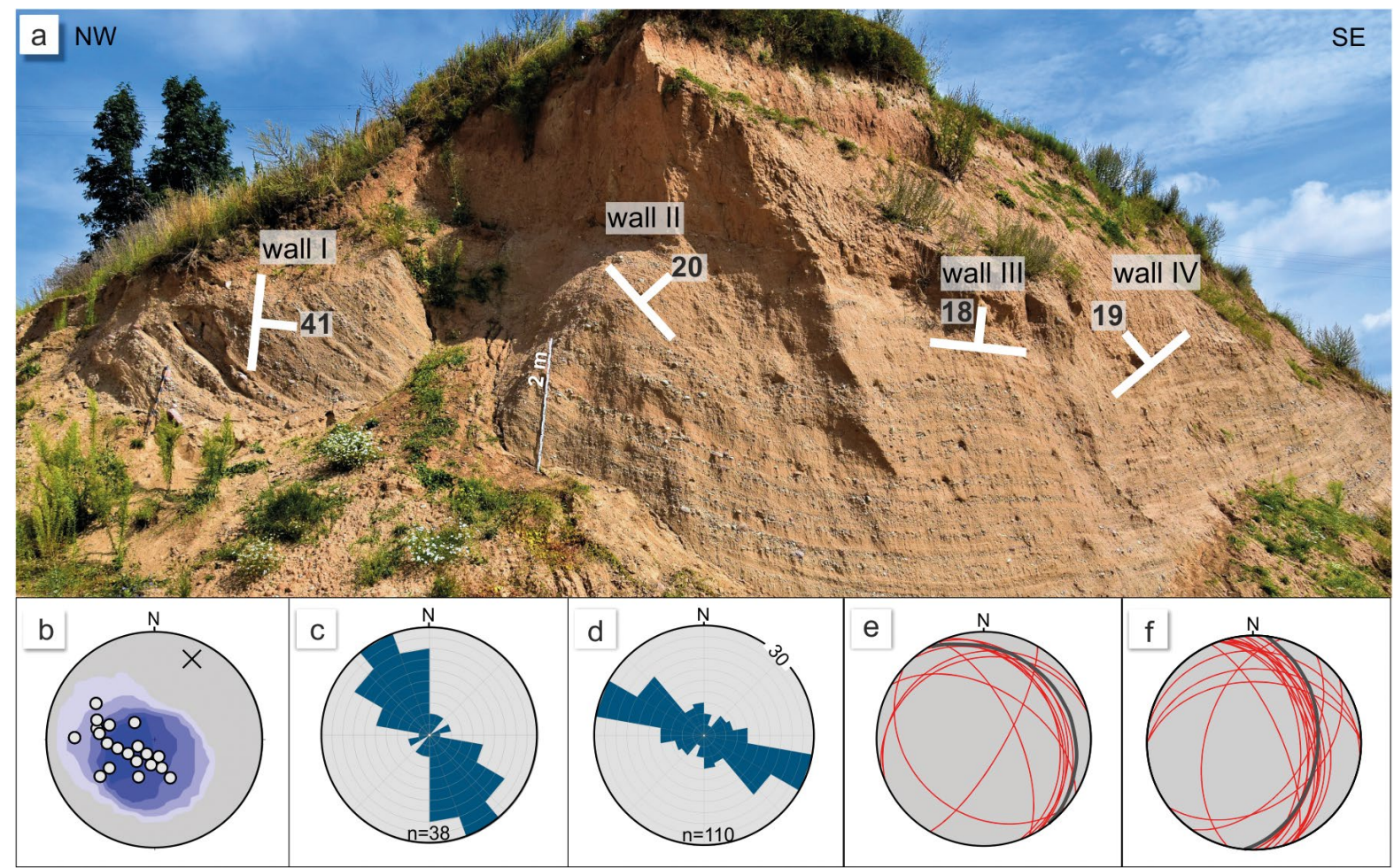

Figure 3. Diagrams presenting results of field measurements. (a) Glaciotectonic deformed glaciofluvial sediments with location of studied walls I-IV (part A of the outcrop, Fig. 2). Ruptured pebbles observations and measurements were provided within walls I and II. Mean bedding plane orientations for walls I-IV was marked with dip and strike symbol. (b) Stereographic projection (lower hemisphere) of the fold axis trend and plunge (cross mark) calculated on the base of poles to bedding orientation measured within walls I-IV (marked as dots). (c) Rose diagram with azimuths of pebbles within glaciofluvial sediments from part A of the outcrop. (d) Rose diagram with a-axis azimuths of pebbles within overlying glacial diamicton (till fabric) in parts B and C of the outcrop. (e-f) Stereographic projections (lower hemisphere) of fracture planes in ruptured pebbles (red great circles) compared to mean bedding plane orientations (black great circles) for I and II walls.

\section{Results}

\subsection{Sedimentary succession}

The sedimentary succession at the Koczery site contains gravelly and sandy sediments, with glacial diamicton emplaced above it. Gravelly and sandy sediments are poorly sorted and dominated by horizontally bedded gravels, gravelly sands and sands (lithofacies Gh, SGh, Sh). Additionally, a secondary, less-frequent lithofacies is present with massive gravels (lithofacies $\mathrm{Gm}$ ) and occasional massive fines (lithofacies Fm). Thickness of these lithofacies varies between a few centimetres and
25 centimetres, all forming sheet-like beds. Basal and top contacts of these lithofacies are usually gradational. Rhythmic sediments were recognized in the succession $\mathrm{Gh} / \mathrm{GSh} \rightarrow \mathrm{SGh} / \mathrm{Sh}$ (Fig. 2). All sediments show four different inclinations. The mean orientation of the bedding planes (part A, Fig. 3a) in the most northwestern part of the studied site is oriented: 1$)$ in wall I $-96 / 41(6 / 41 / \mathrm{E}) ; 2)$ in wall II - 48/20 (318/20/NE); 3) in wall III - 6/18 (96/18/NNE); and 4) in wall IV - 300/19 (210/19/ WNW). All of these sediments from walls I-IV form the limbs of the synclinal open fold, with a calculated fold axis inclination of $25 / 19$ plunging to the NNE (Fig. 3b). In these bedded sediments, 
both intact and ruptured pebbles are commonplace (Fig. 4), with a mean trend of a-axis azimuth measured at NNW-SSE (Fig. 3c). The fabric orientation (NNW-SSE) in glacial diamictons covering the gravelly and sandy sediments in the middle part of the outcrop (sites B and C; Figs. $1 \mathrm{~d}$ and $3 \mathrm{~d}$ ) corresponds to the fold vergence in underlying sediments (Fig. 3b).

\subsection{Pebbles shape and roundness}

Pebbles from glaciofluvial sediments and from glacial diamicton display large heterogeneity in relation to their size range and roundness. Two dominant pebble classes are subangular and subrounded occurring in glaciofluvial sediments at $35 \%$ and $31 \%$, and in glacial diamicton at $49 \%$ and $20 \%$, respectively. The third dominant class, fractured pebbles reaches $25 \%$ in glaciofluvial sediments and $23 \%$ in glacial diamicton. Rounded pebbles in both kinds of sediments did not exceed $10 \%$. In glaciofluvial sediments angular pebbles were absent, whereas in glacial diamicton they reached $5 \%$ (Fig. 5a).

The shape of the pebbles in both glacigenic sediments (glacial diamicton and glaciofluvial sediments) ranges from very-oblate and oblate, through blade and subequant spheroid to prolate spheroid. Roller and discoid pebbles occur very rarely, as do equant spheroid grains, which occur only in glaciofluvial sediments (Fig. 5b). In glaciofluvial sediments the shape of ruptured pebbles varies from discoid to very oblate spheroid, as well as spheroid and roller; whereas in glacial diamicton there is no identifiable shape preference to pebble fracturing (Fig. 5b). Furthermore, in glaciofluvial sediments subangular $(48 \%$ of ruptured pebbles) and subrounded pebbles (44\% of ruptured pebbles) dominates within the fractured pebbles. Single rounded-shape pebbles were fractured (Fig. 5c). In glacial diamicton, mainly subrounded pebbles were fractured. Among subrounded pebbles ruptured clasts reach $60 \%$, while subangular and rounded are just $15 \%$ each (Fig. 5c).

\subsection{Petrographical characteristics of pebbles}

Pebbles from the glaciofluvial sediments were divided into two groups: 1) ruptured pebbles surrounded by sandy and silty-sandy matrix; and 2) intact pebbles adjoining to the ruptured pebbles (Fig. 5d). The petrographic composition was analysed separately for those two groups. In the first group, ruptured pebbles consists of $49 \%$ of Palaeozoic limestones, $26 \%$ of crystalline rocks and $25 \%$ of sandstones/mudstones. In the second group, intact pebbles adjoining to the ruptured pebbles contain $67 \%$ Palaeozoic limestones, $31 \%$ crystalline rocks and only $2 \%$ sandstones/ mudstones. Only one significant difference was found in the petrographic composition of either ruptured or intact pebbles adjoining to the ruptured pebbles - the percentage of sandstones and mudstones is smaller in intact pebbles adjoining to the ruptured pebbles than in the ruptured pebbles ( $2 \%$ to $25 \%$; Fig. $5 \mathrm{~d}$ ).

\subsection{Fracture planes in the ruptured pebbles}

Two main groups of ruptured clasts were recognized in gravel, gravelly sand and sandy gravel lithofacies. A major group of fractures within pebbles are found parallel or subparallel to bedding planes in walls I and II, so the dominant azimuth of the pebble fracture planes is NWN-SES (NW-SE) with a dip ranging between $16-75^{\circ}$ (average $28^{\circ}$; Fig. 3e, f). Another group consists primarily of secondorder, conjugate fractures oriented perpendicular to the dominant azimuth (Figs. 3e, $\mathrm{f}$ and 5a). A characteristic feature of the ruptured pebbles in the glaciofluvial sediments of Koczery site is their occurrence along boundaries between lithofacies; the boundaries that often form pebble lags (Fig. 4a, b, e). In many cases, ruptured pebbles are separated by the intact pebbles adjoining to the ruptured pebbles of different fractional sizes from $0.5 \mathrm{~cm}$ to a few $\mathrm{cm}$, or by sand grains (Fig. 4e, f). Often, ruptured pebbles contain more than one planar 

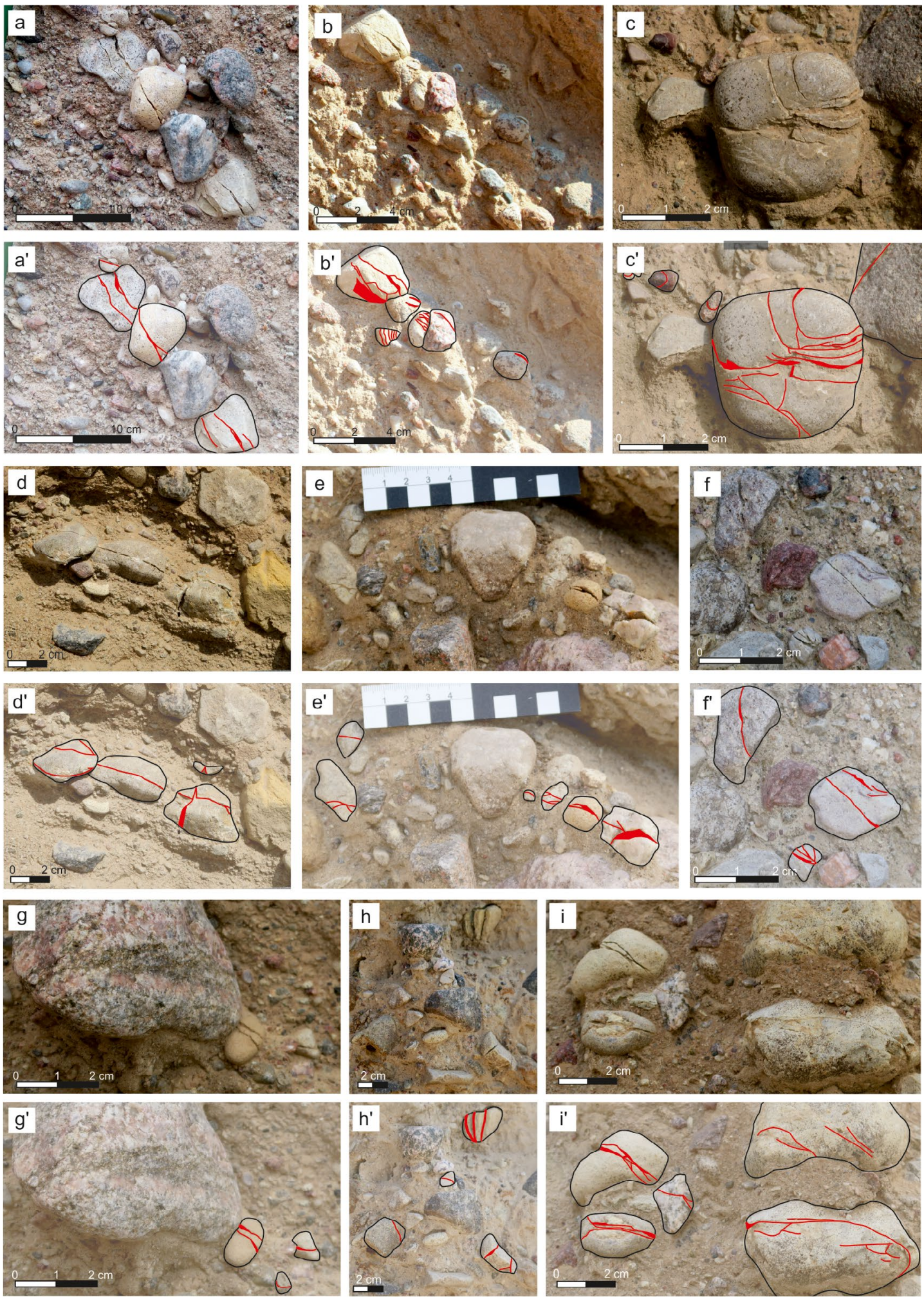

Figure 4. Ruptured pebbles within glaciotectonic deformed glaciofluvial sediments (A-I) and their interpretations $\left(A^{\prime}-I^{\prime}\right)$. 


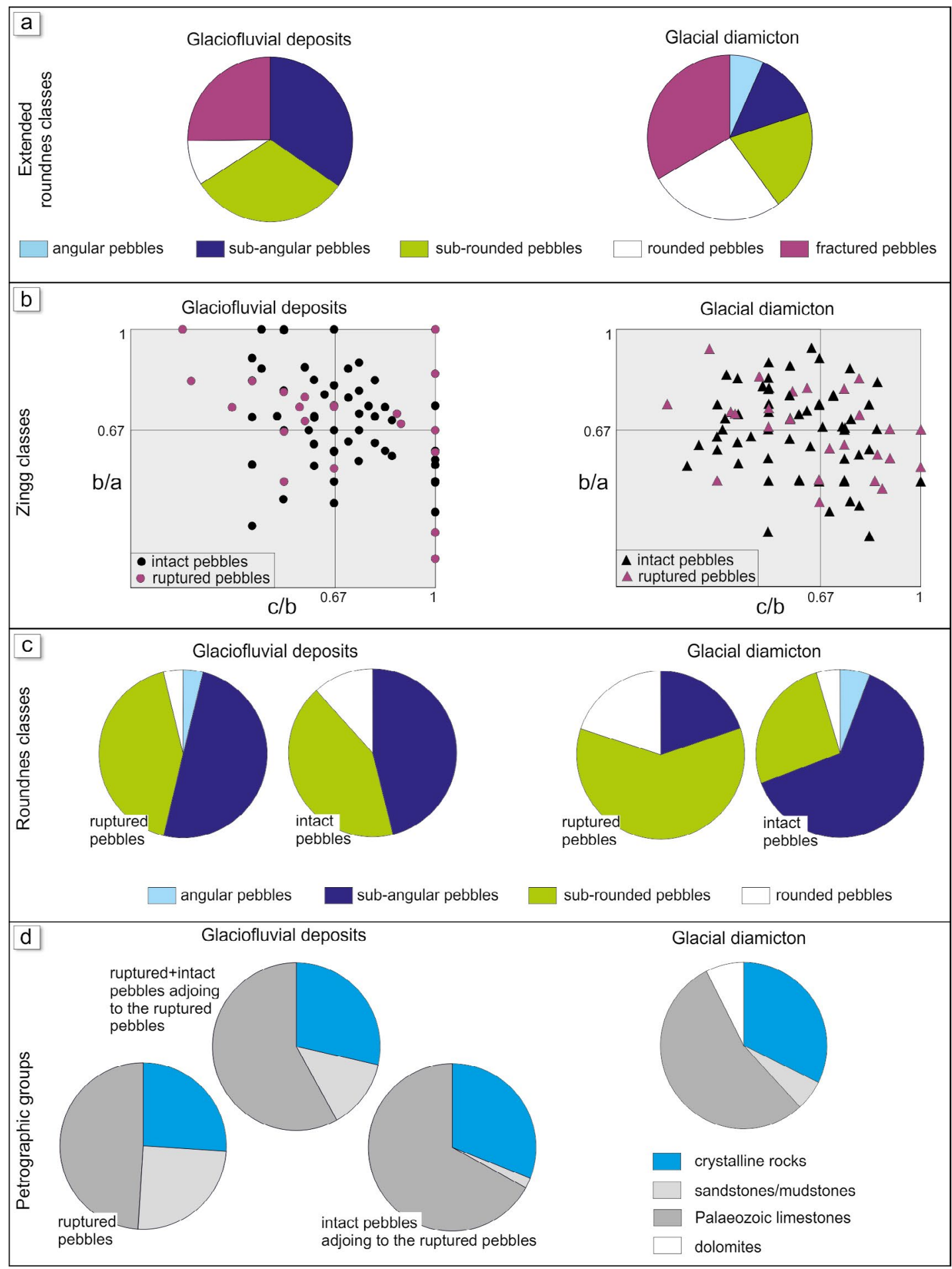

Figure 5. Diversity of ruptured and intact pebbles in glaciofluvial sediments and glacial diamicton at the Koczery site. (a) Pebble roundness according to extended classes, following Olsen (1983). (b) Shape of ruptured and intact pebbles according to classification of Zingg (1935). (c) Pebble roundness according to the scale of Reichelt (1961). (d) Petrographic groups in glaciofluvial sediments (general and divided into ruptured and intact) and in glacial diamicton. 
fracture that is parallel to another (mainly in $2 s$ or $3 \mathrm{~s}$ ), and that matched fracture plane orientation is commonly parallel to the a-axes or to the c-axes of the ruptured pebbles regardless of pebble azimuth (Fig. 4a, a', b, b', d-i'). The main planar fractures occur together with smaller concave fractures (Fig. $\left.4 a, a^{\prime}, i, i^{\prime}\right)$. In some cases the pebble planar fractures are wedge-shaped and opened (mode I). In those instances, the compressive stress was perpendicular to one or another plane of a wedge-shaped fracture (Fig. 4a, a'; Lawn \& Wilshaw, 1975). The ruptured pebbles at the Koczery site did not appear to be associated with movements along planar fractures such as sliding and tearing processes (modes II and III). There are also some fracture planes that failed to cleave the whole pebble and they are marked as pseudo-listric fractures (Fig. 4i, i'). Concave fracture planes very rarely occur, but can exist in association with a set of similarly shaped fractures (Fig. 4c, c'). Occasionally the disintegration process of the pebbles became very intensive (Fig. 4b, b'). Commonly, multiple fractures occur in Palaeozoic limestones and sandstone/mudstones, while in crystalline rocks (granitoids) the maximum limit is two fractures (Fig. 4d, d').

\section{Discussion}

\subsection{Palaeoenvironment reconstruction}

The maximum extent of Saale glaciation is $-30 \mathrm{~km}$ south and southeast from the Koczery site (Marks et al., 2017, 2018). Glaciofluvial sediments and overlying glacial diamicton in the Koczery site were deposited during one Saale glaciation according to Górska (2003). This point is supported by the petrographic analysis; gravels derived from both sediments are almost identical (Palaeozoic limestones $-58 \%$ in glaciofluvial sediments and $54 \%$ in glacial diamicton, crystalline rocks $-31 \%$ and $32 \%$, mudstone/sandstone $-5 \%$ and $6 \%$, dolomite $7 \%$ and $7 \%$, respectively). It is likely that the sediments of the glaciomarginal fan were deposited during a relatively long recessional stage of Warta Stadial during Odranian Glaciation (Saale). Bedded and massive gravels, gravelly sands, sandy gravels and sands that comprise the glaciomarginal fan indicate the past presence of currents in the upper flow regime (cf. Harms et al., 1982) with a planar-bed accretion, the current too strong and too shallow to form riverine dunes, or the glaciofluvial fan sediments were frozen making channel erosion impossible during water floods. The non-channelized occurrences of bedded and massive sediments here are thought to represent shallow, flashy currents of the sheetflood type (cf. McKee et al., 1967; Miall, 1977). Rhythmites of altering gravels/gravelly sands and sandy gravels and sands $-\mathrm{Gh} / \mathrm{GSh} \Rightarrow \mathrm{SGh} / \mathrm{Sh}$ - can be attributed to flood-flow pulses (cf. Pisarska-Jamroży, 2006, 2008). During a short period of waning flow, some thin beds of fines were deposited (lithofacies Fm). All lithofacies were deposited southwards on a palaeoslope of this glaciomarginal fan. A highly aggradational rate of deposition of gravelly and sandy glaciofluvial sediments was responsible for accumulation of poorly sorted sediment and chaotically oriented gravels within the sediments. Afterwards, a re-advance of ice sheet caused deformations of these previously deposited sediments. Parts of the original horizontally bedded and massive sediments were later glaciotectonically deformed en block causing reorientation of beds, which were inclined between $38-40^{\circ} \mathrm{SE}$ and between $70-76^{\circ} \mathrm{SE}$ (Fig. 3a). Two distinct inclined en block deformations may indicate that the ice front surrounded the glaciomarginal fan from W and NW (Fig. 3) causing such specific, differentoriented deformations, but this issue needs more investigation. Moreover, the fabric orientation in the glacial diamicton indicates the ice sheet advance went from NNE and NW (Fig. 3d), which corresponds to the fold vergence in the glaciofluvial sediments. 


\subsection{Glaciotectonic deformation and ruptured pebbles formation-conditions and processes}

In the glacigenic sediments of the Koczery site, the occurrence of ruptured pebbles had not been previously described. The glaciofluvial sediments and the glacial diamicton both contain a similar percentage of ruptured pebbles (Fig. 5a), which might support a conclusion that ruptured pebbles found within glaciofluvial sediments were redeposited. We suggest that commonly occurring fractures noted in numerous pebbles within the glaciofluvial sediments are specifically linked to the glaciotectonic deformation processes at a time when compressional stress $\left(\delta_{1}\right)$ influenced the pebbles during the ice sheet advance (see section 5.1).

Blenkinsop (2002), analysing microcracks in sandy grains, states that fracture formation depends on the packing arrangement of grains, size of clasts, sorting of sediments and grain shape. In the glaciofluvial sediments at the Koczery site almost all pebbles with fractures are derived from the coarsegrained lithofacies Gh and GSh. Moreover, in the lower part of poorly sorted and tightly stacked gravelly lithofacies $\mathrm{Gh}$, deposition took place as pebble lags, in which pebbles were in direct contact with other pebbles (point and long contacts occur), or in the interstitial space occurred as granules or coarse sand (Fig. 4). The tightly packed arrangement of pebbles in the Gh lithofacies preferentially supported double-sided contact loading with their adjacent pebbles, because the pebble shape varies from discoid through blade and subequant spheroid to prolate spheroid (Fig. 5b).

Such structural and textural attributes enabled pebbles to fracture in the stress field created upon loading a plane surface by a spherical object (Hertzian configuration) or by two spheres loading upon each other (Blenkinsop, 2002). In both configurations the maximum compressive stresses acted immediately below the contact point of the two surfaces (see pebbles in Fig. 6a). In the studied glaciofluvial sediments, a Hertzian configuration of pebbles could have occurred exclusively between a discoid pebble that was strongly curved along its a-axis (a plane surface) and another rounded pebble (a sphere, Figs. 4, 6b). However, the results suggest that the most frequent stress field configuration is the case of two rounded pebbles (spheres) loading upon each other (Fig. 4). This process of fracturing was found to be widespread in the studied glaciofluvial sediments, because ruptured pebbles quite often occurred between more resistant intact crystaline rocks or Palaeozoic limestones (Fig. 5d). Additionally, mostly coarse-grained quartz sand and fine-grained gravel located in the matrix between ruptured pebbles were an agent of conduction due to their quite high fracturing resistance. According to experiments conducted by Wright (1995) and Wright et al. (1998), after 24 hours of crushing of one kilogram of quartz grains $(1.0-1.4 \mathrm{~mm})$ in a glacial environment, 47 grams of silty-sized quartz fragments are produced. This confirms the remarkably high resistance of quartz to mechanical damage (Assallay et al., 1998; Goździk \& Mycielska-Dowgiałło, 1982). It is also possible that ruptured pebbles had inherent weakness zones or microcracks, which were enhanced and further developed in the space located between grains in glacial environments. These phenomena can facilitate the crushing process during postdepositional conditions (Hiemstra \& Rijsdijk, 2003).

During glaciotectonic deformation processes, the horizontal stress differences are cumulated over distance and the ice sheet lateral pressure gradient is greatest near the ice margin (Aber \& Ber, 2007). Fractured boulders within the drumlins in the Dollard area in Saskatchewan were also linked to '...more lateral than vertical relief from the compressional force', which was developed during flow of ice around drumlins (Kupsch, 1955). Poorly sorted, glaciofluvial sediments at the Koczery site had their sediment pores infilled by water and afterwards by ice; stress caused by subsequent glaciotectonic processes affected the frozen sediments. Permafrost conditions in the front and/or beneath of the advancing ice sheet can 


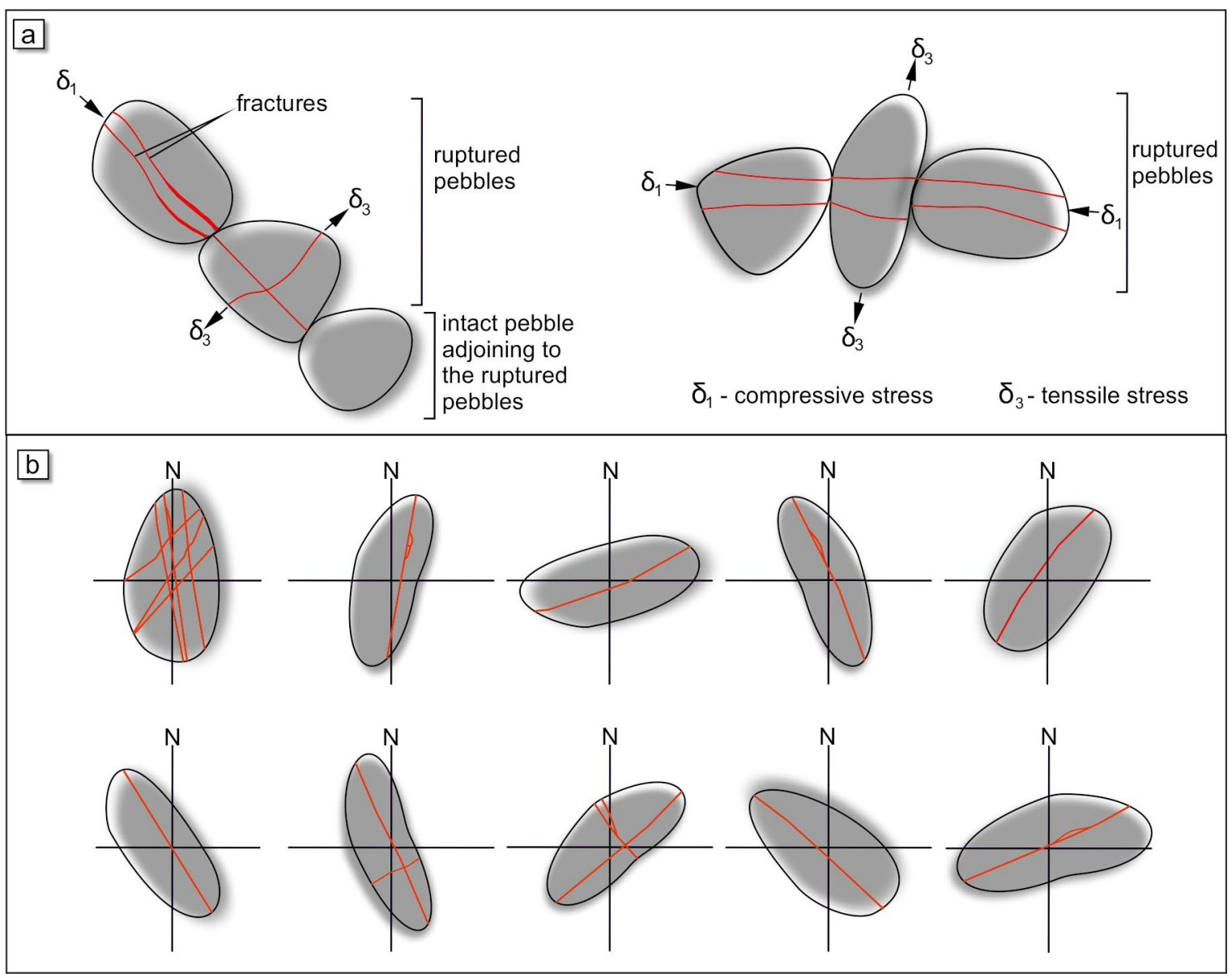

Figure 6. Sketches of ruptured pebble. (a) Examples of ruptured pebble distribution and grain contacts (point and long contacts are visible) compared to interpreted compressive and tensile stress directions. (b) Examples of ruptured pebble orientation in the glaciofluvial sediments and orientation of fracture planes within them.

be supported by following evidence: 1) the Koczery site occurs in marginal part of ice sheet extent; 2) the presence of detached blocks (soft-sediments rafts) with primary structures in glacial diamicton directly overlying the glaciofluvial sediments, (the glaciofluvial sediments were in semi-consolidated frozen state; e.g. Ruszczyńska-Szenajch, 1987; Aber, 1988; Burke et al., 2009; Vaughan-Hirsch et al., 2011, 2013; Pisarska-Jamroży \& Zieliński, 2012; Weckwerth \& Pisarska-Jamroży, 2015), 3) the sharp contact of the glacial diamicton and the lack of deformation in the underlying glaciofluvial deposits caused by the frozen horizon beneath the ice sheet (Szuman et al., 2013; Salomon, 2016) and 4) the presence of vertical dykes developed as an effect of hydrofracturing due to the escape of pressurized groundwater caused by impermeable frozen coarsegrained glaciofluvial sediments (e.g., Evans et al., 2006; Roberts et al., 2009).

Glaciotectonic processes primarily caused the development of en block and brittle deformations, resulting in the normal and reverse faults found in the upper part of these glaciofluvial sediments. Stresses transmitted through the solid mass of ice (Kupsch, 1955) caused a crushing of tightly packed pebbles in the Gm and Gh lithofacies. The architecture of the fractures is found to be independent of clast size, shape and petrography (Fig. 4). The fractures in ruptured pebbles of glaciofluvial sediments were developed as a result of 


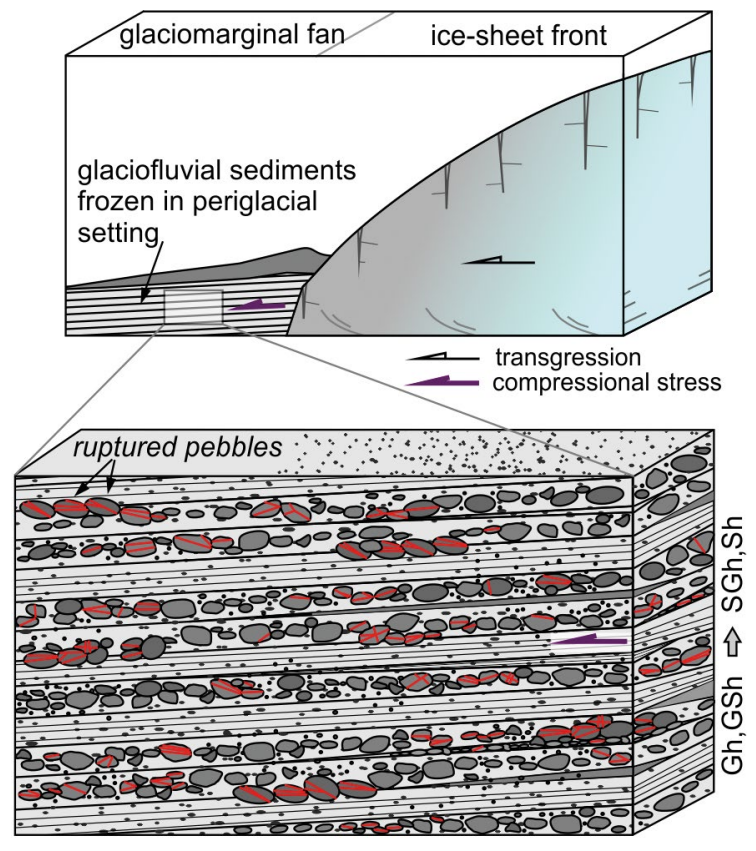

Figure 7. Model of the glaciofluvial sediment deformation during the first stage of ice sheet transgression and ruptured pebble development in frozen glaciofluvial sediments. See section 5 for detailed explanation.

the effect of glaciotectonic deformations, because: 1) fractures occur mostly parallel to the a-axes or to the c-axes of the ruptured pebbles regardless of pebble azimuth; 2) ruptured pebbles occur almost always alone; 3) fractures occur in pebbles regardless of petrographic groups; 4) in most cases all broken parts of ruptured pebbles survived in sediment, which evinces they were most likely damaged in situ and 5) most of fractures are parallel to the direction of the ice sheet transgression (see $\delta_{1}$ at Fig. 6a and Fig. 4a, a', d, d' e, e'). Ruptured pebbles in glacial diamicton are dispersed in overall matrix or occur in groups. The pebble fractures in glacial diamicton arise only in the pebble clusters of subglacial conditions, where smaller grains were trapped between larger grains (Boulton et al., 1974), and in the active transport zone, where ice sheet grains have been crushed due to the failure of pebble bridges. In such conditions, fracturing can begin even under relatively moderate values of normal and shear stresses (Boulton et al., 1974). It seems that the fracturing of pebbles in glaciotectonically deformed sediments occurred in the first stage of deformation (beginning of transgression; see Fig. 7). Under these conditions, compressional stress $\left(\delta_{1}\right)$ affecting the tightly packed pebbles in the massive or horizontally bedded and frozen sediments was parallel to the bedding of glaciofluvial sediments, and thus also to the lab beds. Further deformation of glaciofluvial sediments resulted in the compression stress acting at an increasing angle in relation to the changing arrangement of coarse-grained sediments that became weaker, because they were separated by sands or granules, within which stress was released. Probably the ice-sheet transgression was relatively fast, because there is no evidence of ruptured pebble reorientation within coarse grained sediments; displacement occurs only occasionally within pebbles that are perpendicular to the fracture plane (tensile or opening mode according to Blenkinsop, 2002; Figs. 4, 6), whereas displacement parallel to the fractures plane does not occur (shear mode according to Blenkinsop, 2002).

\section{Conclusions}

Based on our results, the following conclusions can be made:

- Glaciofluvial sediments were glaciotectonically deformed.

- Most of fractures in clasts occur along lithofacies boundaries.

- Two dominant groups of fracture-plane orientations have been recognized: 1) those parallel/subparallel to the sediment bedding plane; and 2) a minor group that is perpendicularly oriented to the sediment bedding plane. Moreover, fracture-plane orientations do correlate with a-axes or c-axes orientation.

- The architecture of the fracture planes does not depend on clast size, shape, roundness or petrography. Diversity of clast size, shape, 
roundness and petrography is a manifestation of the rapid accumulation, fast aggradation rate of glaciofluvial sediments in the proximal part of the glaciomarginal fan and the source area; therefore, the gravel distribution depended on depositional conditions and occurrence of fractured planes was dependent on location of clasts between the limits of lithofacies.

- Orientation of fracture planes in pebbles and till fabric are discordant; the fracture planes have no apparent correlation with the direction of the icesheet advance.

Pebble-fracture analysis may be helpful in indicating palaeostress and in reconstructing of local stress directions. They have also been used as a tool in recognising tectonic activity and earthquake hazard.

\section{References}

Aber, J.S., 1988. Ice-shoved hills of Saskatchewan compared with Mississippi Delta mudlumps: implications for glaciotectonic models. In: Croot, D.G. (ed.), Glaciotectonic Forms and Processes, 1-9. Balkema, Rotterdam.

Aber, J. \& Ber, A. (eds.), 2007. Glaciotectonism. Developments in Quaternary Sciences 6, $246 \mathrm{p}$. https://doi.org/10.1016/s1571-0866(07)x8067-9

Assallay, A.M., Rodgers, C.D.F., Smalley, I.J. \& Jefferson, I., 1998. Silt: 2-62 $\mu \mathrm{m}, 9-4 \varphi$. Earth-Science Reviews 45, 61-88. https://doi.org/10.1016/S0012-8252(98)00035-X

Badura, J., Przybylski, B., Tokarski, A. \& Świerczewska, A., 2007. Tarasy rzeczne Nysy Kłodzkiej oraz drobne plejstoceńskie struktury tektoniczne w strefie sudeckiego uskoku brzeżnego i przełomu bardzkiego w Janowcu [Terraces of Nysa Kłodzka river and small-scale tectonic structures close to the Sudetic Marginal Fault at Janowiec (Bardo Mts.)]. Przegląd Geologiczny 55, 9-28 [in Polish with English abstract].

Benn, D.I., 2004. Macrofabric. In: Evans, D.J.A. \& Benn, D.I. (eds.), A practical guide to the study of glacial sediments. Arnold, London, 93-114.

Bradley, D.C. \& Bradley, L.M., 1986. Tectonic significance of the Carboniferous Big Pond Basin, Cape Breton Island, Nova Scotia. Canadian Journal of Earth Sciences 23, 2000-2011.

https://doi.org/10.1139/e86-185
However, results of our investigation suggest the glaciotectonic processes as an alternate formational factor that may have caused pebble fracturing in sediments located within glaciofluvial sediments. Therefore, the occurrence of ruptured pebbles in a study site alone should not be treated as an unequivocal indicator of active tectonic processes.

\section{Acknowledgements}

The GREBAL project is financially supported by a grant from the National Science Centre, Poland No. 2015/19/B/ST10/00661. Mark Demitroff (Stockton University, USA) is thanked for English proof-reading that significantly improved our manuscript. We thank both reviewers for valuable suggestions.

Broster, B.E. \& Clague, J.J., 1987. Advance and retreat glacigenic deformation at Williams Lake, British Columbia. Canadian Journal of Earth Sciences 24, 14211430 . https://doi.org/10.1139/e87-134

Blenkinsop, T.G., 2002. Deformation microstructures and mechanisms in minerals and rocks. Kluwer Academic Publishers, Dordrecht, $150 \mathrm{p}$. https://doi.org/10.1007/0-306-47543-X

Boulton, G.S., Dent, D.L. \& Morris, E.M., 1974. Subglacial shearing and crushing, and the role of water pressures in tills from South-East Iceland. Geografiska Annaler 56A, 135-145. https://doi.org/10.2307/520703

Burke, H., Philips, E., Lee, J.R. \& Wilkinson, I.P., 2009. Imbricate thrust stack model for the formation of glaciotectonic rafts: an example from the Middle Pleistocene of north Norfolk, UK. Boreas 38, 620-637. https://doi.org/10.1111/j.1502-3885.2009.00085.x

Cuong, N.Q., Tokarski, A., Świerczewska, A. \& OliwkiewiczMiklasińska, M., 2001. An approach to the structural history during Cenozoic of the Lo river fault (North Vietnam). Journal of Geology 17-18B, 45-53.

Decker, K. \& Peresson, H., 1996. Rollover and hanging-wall collapse during Sarmatian/ Pannonian synsedimentary extension in the Eisenstadt basin. Mitteilungen der Gesellschaft der Geologie und Bergbaustudenten in Österreich 41, 45-52. 
Eidelman, A. \& Reches, Z., 1992. Fractured pebbles-a new stress indicator. Geology 20, 307-310. https://doi.org/10.1130/0091-7613(1993)021<0187:fp ansi>2.3.co;2

Evans, D.J.A., Phillips, E.R., Hiemstra, J.F., Auton, C.A., 2006. Subglacial till: formation, sedimentary characteristics and classification. Earth-Science Reviews 78, 115-176. https://doi.org/10.1016/j.earscirev.2006.04.001

Górska, M., 2003. Analiza petrograficzna narzutniaków skandynawskich [Petrographic analysis of Scandinavian Boulders]. In: Harasimiuk, M. \& Terpiłowski, S. (eds.), Analizy sedymentologiczne osadów glacigenicznych [Sedimentological analyses of glacigenic deposits]. UMCS Press Lublin, 23-31 [in Polish].

Górska, M., 2006. Fennoscandian erratics in glacial deposits of the Polish lowland-methodic aspects. Studia Quaternaria 23, 11-15.

Goździk, J. \& Mycielska-Dowgiałło, E., 1982. Badania wpływu niektórych procesów geologicznych na przekształcenia powierzchni ziarn kwarcowych [Influence of different geological processes on quartzgrain surface deformation]. Przegląd Geograficzny 54, 219-240 [in Polish with English abstract].

Grützner, C., Reicherter, C., Hübscher, C. \& Silva, P.G., 2012. Active faulting and neotectonics in the Baelo Claudia area, Campo de Gibraltar (southern Spain). Tectonophysics 554-557, 127-142. https://doi.org/10.1016/j.tecto.2012.05.025

Harms, J.C., Southard, J.B. \& Walker, R., 1982. Structures and Sequences in Clastic Rocks. SEPM Short Course Notes 9, $253 \mathrm{p}$.

Hiemstra, J.F. \& Rijsdijk, K.F., 2003. Observing artificially induced strain: implications for subglacial deformation. Journal of Quaternary Science 18, 373-383. https://doi.org/10.1002/jqs.769

Hippolyte, J.-C., 2001. Palaeostress and neotectonic analysis of sheared conglomerates: Southwest Alps and Southern Apennines. Journal of Structural Geology 23, 421-429. https://doi.org/10.1016/S0191-8141(00)00120-6

Kinnunen, K.A., 2007. Fractured siltstones in Susivuori esker close to Susiluola cave, Karijoki, Finland. Fennoscandia Archaeologica 24, 57-63.

Kübler, S., Friedrich, A.M., Gold, R.D. \& Strecker, M.R, 2017. Historical coseismic surface deformation of fluvial gravel deposits, Schafberg fault, Lower Rhine Graben, Germany. International Journal of Earth Sciences 106, 11-15. https://doi.org/10.1007/s00531-017-1510-9

Kupsch, W.O., 1955. Drumlins with jointed boulders near Dollard, Saskatchewan. Geological Society of America Bulletin 66, 327-338. https://doi.org/10.1130/0016-7606(1955)66[327:dwjb nd] 2.0.co;2

Lamb, S.H. \& Bibby, H.M., 1989. The last 25 MA of rotational deformation in part of the New Zealand plate-boundary zone. Journal of Structural Geology 11, 473-492. https://doi.org/10.1016/0191-8141(89)90024-2
Lawn, B. \& Wilshaw, R., 1975. Indentation fracture: principles and applications. Journal of Materials Science 10, 10491081.

https://doi.org/1049-1081. 10.1007/BF00823224

Little, T.A., 1995. Brittle deformation adjacent to the Awatere strike-slip fault in New Zealand: Faulting patterns, scaling relationships, and displacement partitioning. Geological Society of America Bulletin 107, 1255-1271. https://doi.org/10.1130/00167606(1995) 107<1255:BDATTA>2.3.CO;2

Marks, L., Karabanov, A., Nitychoruk, J., Bahdasarau, M., Krzywicki, T., Majecka, A., Pochocka-Szwarc, K., Rychel, J., Zbucki, Ł., Hradunova, A., Hrychanik, M., Mamchyk, S., Rylova, T., Nowacki, Ł. \& Pielach, M., 2017. Zasięg i recesja lądolodu zlodowacenia odry/prypeci w strefie pogranicza polsko-białoruskiego. In: Marks, L. \& Karabanov, A. (eds.), Geological Map of southern part of Polish-Belarusian cross-bourder area. Biała Podlaska and Brest region 1: 250 000. PIG-PIB press, Warsaw, 88-91 [in Polish].

Marks, L., Karabanov, A., Nitychoruk, J., Bahdasarau, M., Krzywicki, T., Majecka, A., Pochocka-Szwarc, K., Rychel, J., Woronko, B., Zbucki, Ł., Hradunova, A., Hrychanik, M., Mamchyk, S., Rylova, T., Nowacki, Ł. \& Pielach, M., 2018. Revised limit of the Saalian ice sheet in central Europe. Quaternary International 478, 59-74. https://doi.org/10.1016/j.quaint.2016.07.043

McCaffrey, R.J. \& McCann, N., 1992. Post-Permian basin history of northeast Ireland. In: Parnell, J. (ed.), Basins on the Atlantic seaboard: Petroleum geology, sedimentology and basin evolution. Geological Society of London, Special Publication 62, 277-290. https://doi.org/10.1144/GSL.SP.1992.062.01.22

McKee, E.D., Wilson, R.F., Breed, W.J. \& Breed, C.S., 1967. Evolution of the Colorado River in Arizona. Museum of Northern Arizona Bulletin 44, 67 p.

Miall, A.D., 1977. A review of the braided-river depositional environment. Earth-Science Reviews 13, 1-62. https://doi.org/10.1016/0012-8252(77)90055-1

Nitychoruk, J., Dzierżek, J. \& Stańczuk, D., 2009. Objaśnienia do Szczegółowej Mapy Geologicznej Polski 1:50 000 [Explanatory text to the Detailed Geological Map of Poland 1:50 000]. sheet Drohiczyn 494, PIG-PIB press, 33 p. [in Polish].

Nývlt, D. \& Hoare, P.G., 2011. Petrology, provenance and shape of clasts in the glaciofluvial sediments of the Mníšek member, northern Bohemia, Czechia. Journal of Geological Sciences 27, 5-22.

Olsen, L., 1983. A method for determining total clast roundness in sediments. Boreas 12, 17-21. https://doi.org/10.1111/j.1502-3885.1983.tb00355.x

Owen, L.A., 1989. Neotectonics and glacial deformation in the Karakoram Mountains and Nanga Parbat Himalaya. Tectonophysics 163, 227-265. https://doi.org/10.1016/0040-1951(89)90260-6 
Pisarska-Jamroży, M., 2006. Transitional deposits between end-moraine and sandur plain in the Pomeranian glaciomarginal zone of NW Poland: a missing component of ice-contact sedimentary models. Boreas 35, 126-141. https://doi.org/10.1111/j.1502-3885.2006.tb01117.x

Pisarska-Jamroży, M., 2008. Zonation of glaciomarginal environment inferred from Pleistocene deposits of Mysliborz Lakeland, NW Poland, Geografiska Annaler 90A, 237-249. https://doi.org/10.1111/j.1468-0459.2008.342.x

Pisarska-Jamroży, M. \& Zieliński, T., 2012. Specific erosional and depositional processes in a Pleistocene subglacial tunnel in the Wielkopolska region, Poland. Gografiska Annaler 94A, 429-443. https://doi.org/10.1111/j.1468-0459.2012.00466.x

Ramsay, D.M., 1962. The Highland Boundary Fault: reverse or wrench fault? Nature 195, 1190-1191. https://doi.org/10.1038/1951190b0

Ramsay, D.M., 1964. Deformation of pebbles in the lower Old Red Sandstone conglomerates adjacent to the Highland Boundary Fault. Geological Magazine 101, 228-248. https://doi.org/10.1017/S0016756800049463

Reichelt, G., 1961. Über Schotterformen und Rundungsgradanalyse als Feldmethode. Petermanns Geographische Mitteilungen 105, 15-24 [in German].

Roberts, D.H., Yde, J.C., Knudsen, N.T., Long, A.J. \& Lloyd, J.M., 2009. Ice marginal dynamics during surge activity, Kuannersuit Glacier, Disko Island, West Greenland. Quaternary Science Review 28, 209-222. https://doi.org/10.1016/j.quascirev.2008.10.022

Ruszczyńska-Szenajch, H., 1987. The origin of glacial rafts: detachment, transport, emplacement. Boreas 16, 101112. https://doi.org/10.1111/j.1502-3885.1987.tb00761.x

Salomon, T., 2016. Subglacial conditions and Scandinavian Ice Sheet dynamics at the coarse-grained substratum of the fore-mountain area of southern Poland. Quaternary Science Reviews 151, 72-87.

https://doi.org/10.1016/j.quascirev.2016.09.002

Szuman, I., Ewertowski, M. \& Kasprzak, L., 2013. Thermomechanical facies representative of fast and slow flowing ice sheets: the Weichselian ice sheet, a central west Poland case study. Proceedings of the Geologists' Association 124, 818-833. https://doi.org/10.1016/j.pgeola.2012.09.003

Tanner, W.F., 1963. Crushed pebble conglomerate of Soutwestern Montana. Journal of Geology 71, 637-641. https://doi.org/10.1086/626937

Tanner, W.F., 1976. Tectonically significant pebble types: sheared, pocked and second-cycle examples. Sedimentary Geology 16, 69-83. https://doi.org/10.1016/0037-0738(76)90013-0

Tapponnier, P., Peltzer, G. \& Armijo, R., 1986. On the mechanics of the collision between India and Asia. In: Coward, M.P. \& Ries, A.C. (eds.), Collision Tectonics.
Geological Society of London, Special Publication 19, 115-157. https://doi.org/10.1144/GSL.SP.1986.019.01.07

Tokarski, A. \& Świerczewska, A, 2005. Neofractures versus inherited fractures in structural analysis: A case study from Quaternary fluvial gravels (Outer Carpathians, Poland). Annales Societatis Geologorum Poloniae 75, 95-104.

Tokarski, A., Świerczewska, A. \& Zuchiewicz, W., 2007. Fractured clasts in neotectonic reconstructions: an example from the Nowy Sącz basin, western outer Carpathians, Poland. Studia Quaternaria 24, 47-52.

Tokarski, A., Márton, E., Świerczewska, A., Fheed, A., Zasadni, J. \& Kukulak, J., 2016. Neotectonic rotations in the Orava-Nowy Targ Intramontane Basin (Western Carpathians): An integrated palaeomagnetic and fractured clasts study. Tectonophysics 685, 35-43. https://doi.org/10.1016/j.tecto.2016.07.013

Tyler, J.H., 1975. Fracture and rotation of brittle clasts in a ductile matrix. Journal of Geology 83, 501-510. https://doi.org/10.1086/628124

Vaughan-Hirsch, D.P., Phillips, E.R., Lee, J.R., Burke, H.F., \& Hart, J.K., 2011. Glacitectonic rafting of chalk bedrock: overstrand. In: Phillips, E., Lee, J.R. \& Evans, H.M. (eds.), Glacitectonics-Field Guide, 198-217. Quaternary Research Association, Pontypool.

Vaughan-Hirsch, D.P., Phillips, E., Lee, J.R., \& Hart, J.K., 2013. Micromorphological analysis of poly-phase deformation associated with the transport and emplacement of glaciotectonic rafts at West Runton, north Norfolk, UK. Boreas 42, 376-394. https://doi.org/10.1111/j.1502-3885.2012.00268.x.

Weckwerth, P. \& Pisarska-Jamroży, M., 2015. Periglacial and fluvial factors controlling the sedimentation of Pleistocene breccia in NW Poland. Geografiska Annaler 97A, 415-430. https://doi.org/10.1111/geoa.12082

Wright, J.S., 1995. Glacial comminution of quartz sand grains and the production of loessic silt: a simulation study. Quaternary Science Reviews 14, 669-680. https://doi.org/10.1016/0277-3791(95)00048-8

Wright, J.S., Smith, B. \& Whalley, B., 1998. Mechanisms of loess-sized quartz silt production and their relative effectiveness: laboratory simulation. Geomorphology 23, 15-34. https://doi.org/10.1016/S0169-555X(97)00084-6

Zelčs, V. \& Dreimanis, A., 1997. Morphology, internal structure and genesis of the Burtnieks drumlin field. Sedimentary Geology 111, 73-90. https://doi.org/10.1016/S0037-0738(97)00007-9

Zieliński, T. \& Pisarska-Jamroży, M., 2012. Jakie cechy litologiczne osadów warto kodować, a jakie nie? [Which features of deposits should be included in a code and which not?] Przegląd Geologiczny 60, 387-397 [in Polish with English abstract].

Zingg, T., 1935. Beitrag zur Schotteranalyse. Swiss Bulletin of Mineralogy and Petrology 15, 39-140 [in German]. 